\title{
A Comparison of Two Methods of Teaching Research to Master of Social Work Students
}

\author{
Christine Ann Walsh \\ Faculty of Social Work, University of Calgary, Canada \\ E-mail: cwalsh@ucalgary.ca \\ Jennifer Hewson \\ Faculty of Social Work, University of Calgary, Canada \\ E-mail: jahewson@ucalgary.ca
}

Received: March 7, 2012

Accepted: April 23, 2012

Published: May 15, 2012

doi:10.5430/ijhe.v1n1p14

URL: http://dx.doi.org/10.5430/ijhe.v1n1p14

\begin{abstract}
While various curriculum strategies have been presented for teaching research, little is known about the effectiveness of different teaching approaches. This study compared two models for teaching research to MSW students: a mentorship model (TM1) and a more structured, didactic model (TM2). Students ( $=23$ ) self-completed the Research Self Efficacy questionnaire on the first and last day of class. Repeated measures ANOVA showed that both groups improved over time; however, TM2 students improved significantly more than TM1 students. This study provides preliminary insights and suggestions for further research on different models for enhancing research skills and confidence of social work students.
\end{abstract}

Keywords: Social work student, Mentorship model (TM1), Didactic model (TM2)

\section{Introduction}

An evidence-based practice movement is emerging among social workers in the United Kingdom, Australia, and the United States (Cournoyer, 2004; Gambrill, 2004; Gilgun, 2005; Howard, McMillen \& Pollio, 2003; McNeece \& Thyer, 2004; Rzepnicki \& Briggs, 2004; Smith, 2004; Thyer, 2004). However, the relationship between social work students and research has been described as "reluctant" (Epstein, 1987; Harder, 2010; Wainstock, 1994) or as somewhat less than a "match made in heaven" (Green, Bretzin, Leininger, \& Stauffer, 2001). One study found social work students, particularly those older students or those who report higher levels of social work empowerment exhibited a positive attitude towards research (Secret, Ford, \& Rompf, 2003).

Many social work graduates do not use research in their daily practice (Adam, Zosky, \& Unrau, 2004; Bergmark \& Lundstrom, 2002; Gallagher, Cook, Tebb, \& Berg-Weger, 2003). Further, fewer than half of social workers were involved in research-based activities and many social workers do not read peer-reviewed journals (Fraser, 1993; Fraser, Lewis, \& Norman, 1990; Gantt, Pinsky, Rock, \& Rosenberg, 1990). McCrystal (2000) found that social workers "were generally ill-prepared to understand research processes and methodologies" (p. 359) and unsure about how to turn research findings into practice. Green et al. (2001) compared the self-reported research and computer anxiety and research orientations of social work, psychology, and business students, and found that, "[s]ocial work students reported more research and computer anxiety and generally believed that research was less important to their profession than students in the comparison groups" (p. 333).

One of the difficulties is simply the volume of knowledge: social work research methods range from classical experimental approaches to action research and collaborative research, as well as new approaches like service-user-led research and reflective research (Gibbs, 2001). Cox and Jackson (2003) suggested that social workers need to have an "understanding of a broad range of methods...appropriate in different contexts" (p. 4). Lewis (2003) claimed that social work research will not be able to improve or increase its profile without the use of a whole range of methods.

Hardcastle and Bisman (2003) described three different goals for research education: (1) an Educated Consumer of Research, which focuses on teaching skills of critical thinking and the ability to analyze and assess social work research 
literature, (2) Practitioner Scientist, which focuses on teaching students to become research scientists, to approach case practice and intervention as a research endeavour, and to see research as an opportunity for social science knowledge building, and (3) Research as Practice Methodology, which focuses on critical thinking and the appropriate use of research methodologies in order to become a more capable practitioner. Similarly, Fraser and Lewis (1993) identified four goals: (1) De Rigeur, a range of basic and advanced research and statistical methods, (2) Single-Subject Plus, which emphasizes basic and single-subject research methods, (3) Traditionalist, basic research methods, and (4) Minimalist, with less emphasis on research content overall. According to Cameron and Este (2008), students at the MSW level should be able to discuss different methodologies and the pros and cons of employing different approaches, have an increased comfort level in discussing various research approaches and their main epistemologies, critically evaluate research, and use qualitative and quantitative software. If our goal is evidence-based practice, then schools of social work must prepare students with research skills that will, at the very least, allow them to (1) critically appraise a study to determine whether its findings are sound, and (2) integrate valuable findings into practice.

But what is the "best" way to teach such skills? Rondeau (2001) suggested creating projects that bring together practitioners and professors in education. Cameron and Este (2008) recommended integrating practical research projects into classroom assignments such as analyzing qualitative and quantitative social work research articles. Globerman and Chan (2000) advocated for weekly brief lectures on appraisal questions, topics, and references, and small group and full class review discussions, culminating in an article review assignment. Other suggestions included involving students in an ongoing research program in the faculty (Cameron \& Este, 2008), using agency staff as a co-instructors, directing students to carry out a research project on an actual agency issue (Knee, 2002; Wainstock, 1994), or integrating research within field placements and having practicum supervisors visit classrooms to discuss issues they have researched or would like to research and invite student participation (Cameron \& Este, 2008; Walsh, Shier, Sitter, \& Sieppert, 2010). Montcalm (1999) found that engaging students in agency-based research allows students to understand how the outcomes of their research can influence practice, policy and program change and Machtmes (2009) proposed service-learning approaches. Also, Walsh, Rutherford and Sears (2010) recommended the inclusion of community members as co-learners in teaching and learning about research resulted in benefits for students and members of marginalized communities.

These recommendations are helpful in a practical sense, but they do not advise on the best model of teaching. The purpose of this study was to compare two models for teaching MSW students research skills applicable to practice. Students self-selected either a mentorship model (TM1) or a more structured, didactic model (TM2) social work research course.

\section{Two Models for Teaching Research Methods}

Students in the Master of Social Work Program at the University of Calgary, Calgary Alberta Canada were required to take two terms of research methods in order to help them develop research skills that are applicable to practice and managerial decisions in their professional practice. At the time of the study, faculty members teaching the research methods courses decided to explore the value of using different models for teaching research methods. The faculty had already developed a research-based practicum program (Hewson, Walsh, \& Bradshaw, 2010) but also wanted to include alternative approaches for required research courses, particularly for students with different levels of research knowledge and experience. It was decided that one of the three sections for fall-winter 2009/2010 would implement a mentorship model referred to as Teaching Methodology One (TM1). The other two sections would continue to use a more structured, didactic model referred to as Teaching Methodology Two (TM2). Only one section of TM2 participated in the study.

TM1 and TM2 required an equal number of student hours to complete course work. Both instructors had taught TM2 in the previous year and had been involved in the original conceptualization of the alternative section. Students chose to register for the TM1 or TM2 sections. Generally, students with more research experience and an interest in self-directed learning were encouraged to enrol in TM1, while students who were not as comfortable with research or who preferred a more structured learning environment were encouraged to enrol in TM2.

\subsection{Teaching Methodology One (TM1)}

In TM1, students were presented with the option of working with a Faculty of Social Work mentor on a current project or creating their own project. Mentors were recruited prior to the start of the term and the instructor presented a listing of faculty led projects from which to choose. Students were encouraged to actively engage in the various stages of the research process from design to dissemination, depending on the stage of the project with which they became involved. Once matched with a project and faculty mentor, students created a learning contract in consultation with their mentor and the course instructor. Over the two terms, students completed their learning goals as self-directed learners under the guidance of the mentor with periodic seminars and meetings with the instructor. Students were encouraged to engage 
their fellow students as research colleagues/ assistants and discuss problems encountered and decisions made during their projects. Specific course reading were not assigned; however, students were expected to seek out and read materials applicable to their specific projects. While faculty mentors monitored student learning goals and activities, student learning content and pacing was largely self-directed. Students were encouraged to manage their time so that they would finish their projects within each semester, although the mentor and instructor allowed some leeway, negotiating due dates with students depending on specific student and/or project circumstances. Student projects were diverse; examples included organizing and facilitating a series of focus groups examining conceptualization of elder abuse among South Asian older adults and service providers, collaborating with members of a amateur theatre group whose members included service providers, academics and persons who were homeless, to document their process (Eastham et al., 2010) to a secondary analysis of a qualitative data set examining older women's experiences of homelessness (McLeod \& Walsh, 2012).

\subsection{Teaching Methodology Two (TM2)}

TM2 was delivered in a more traditional didactic format, with a combination of instructor presentations, student presentations, and guest speakers. Class assignments were determined based on core course content and course readings were required. Students were asked to propose a hypothetical research project that would be the basis of their assignments. In the fall semester, students were required to prepare a literature review, formulate a research question, design the research methodology and outline the significance of the proposed study for practice and policy. In the winter semester, students were asked to prepare an abstract, an ethics application, as well as their choice of a (1) poster presentation, (2) research project management plan, (3) manuscript or (4) grant application. The class schedule was set by the instructor and students attended weekly seminars on preselected topics identified in the course outline. Due dates were clearly defined in the course outline by the class instructor with extensions provided for specific student circumstances. Detailed marking rubrics were used to assess all assignments.

\section{Methods}

\subsection{Data Collection}

We compared students in the two sections of the research course; all TM1 and TM2 students were invited to participate. The study was approved by the Conjoint Faculties Research Ethics Board (CFREB) University of Calgary. Those who chose to participate completed the Research Self Efficacy questionnaire (RSE) on the first day of the first term (the "pre-test"), and again on the last day of the second term ("post-test"). The RSE is a 9 item scale designed to assess social work students' confidence in their ability to complete specific research activities (Holden, Barker, Meenaghan, \& Rosenberg, 1999). It has shown good internal consistency (Cronbach's alphas were .94 at both pre-test and post-test), construct validity (five items fell within these $95 \%$ confidence intervals) and sensitivity to change (differences between pre- and post-test scores were statistically significant for all individual items and the total scale score using Wilcoxon signed ranks tests (Holden et al., 1999). The RSE contains items such as how confident are you that you can (a) do effective electronic database searching of the scholarly literature, through (h) design and implement the best data analysis strategy possible, and (i) effectively present your study and its implications; response options were 0 to 10 , giving scores 0 through 90 . At post-test, in addition to the RSE, students were asked 12 items designed by the authors to measure student confidence in various research tasks (see Table 1).

\subsection{Sample}

While the course was required, students were able to self-select their section. Students in both sections were predominantly female with only three males registered, which is typical of the student population for this program. TM1 had fewer students than TM2 and there was some change in the number of students registered across the two terms. TM1 had 13 students in fall 2009 and 11 students continuing in this section in winter 2010. The 11 students who stayed in the section were eligible for the study. TM2 had 17 students in fall 2009 with all of these students continuing in this section in winter 2010, along with an additional seven students who switched over from the other TM2 section or were completing coursework on a part-time basis. These seven students were not eligible to participate in the study since they had not completed the pre-test and had a different first term experience.

In order to minimize potential biases, a research assistant who had no involvement with either section introduced the study, distributed and collected consent forms and surveys, and matched pre- and post-test surveys according to student identification numbers; ID numbers were later removed. Students were informed that their participation was voluntary and that they could refuse to participate altogether or refuse to participate in parts of the study without penalty to their course grade or reputation with the course instructors. They were able to withdraw from the study until the time they submitted their post-test survey. 
The 11 eligible students in TM1 completed surveys and consent forms; however, one student was excluded because there was no pre-test data. All of the original 17 students in TM2 completed surveys; however, two of these students had data but no signed consent form and two were missing pre-test data and were excluded from the analysis. Therefore, the final sample for analysis was 23 (10 TM1 students and 13 TM2 students).

\section{Results}

Figure 1 shows mean scores and standard deviations on the RSE at pre- and post-test for the TM1 and TM2 groups. Repeated measures ANOVA showed a significant main effect for time $(\mathrm{F}(1,21)=43.4$, $\mathrm{p}<.001)$ and for group $(\mathrm{F}(1,21)=13.8, \mathrm{p}=.001)$, and a significant group*time interaction $(\mathrm{F}(1,21)=5.68, \mathrm{p}=.027)$. That is, there was a significant increase over time in RSE scores, groups were significantly different, and TM2 students improved significantly more than TM1 students over the duration of the course. The TM2 group had significantly lower scores than TM1 students at pre-test $(\mathrm{t}(21)=4.0, \mathrm{p}=.001)$ but not at post-test $(\mathrm{t}(21)=1.8, \mathrm{p}=.086)$. Variance in the TM2 group, while not significantly larger, indicated that students in that group showed a greater diversity in their research self-efficacy than students in the TM1 group, at both pre- and post-test.

Table 1 shows mean scores on the additional items collected at post-test, by group. No item was significantly different between groups. Students in both sections of the course reported moderate to high levels of confidence in research tasks. Items assessing the degree to which students recognized that "research utilization is vital to effective social work practice" and that they have "developed confidence in applying research to the real world" received the highest rates of positive endorsement. Students described lower levels of confidence in the "progress in this course with regard to applying the course material to the real world" in comparison to other courses.

\section{Discussion}

The findings of this study present some interesting insights into different models of teaching research to social work graduate students. It is not surprising that the two groups were significantly different at pre-test with the TM2 group having lower scores than the TM1 group. The TM2 section was advertised as the regular section with TM1 promoted as the more advanced, applied section. A number of students contacted the instructors of both sections prior to the start of the course to determine which section would better fit their research needs and experiences. If they had prior research experience or a very strong interest in being part of an actual research project, they were encouraged to take the advanced section, TM1. As such, students who were less comfortable with research tended to choose or were encouraged to enrol in the TM2 section likely resulting in lower levels of self-perceived research skills and confidence initially. It should be noted, however, that there were a number of students in TM2 who had advanced skills but opted to remain in the regular section because they preferred a more structured environment or may have still lacked confidence in their research ability. There were also students in TM1 who had had less research experience but a strong desire to be in a more applied section. Even if their actual skills might not have been higher, a measure which was not assessed in this study, they perceived themselves to be more confident and capable of conducting the diverse applications and skills included in the survey items. It would have been helpful to have had a placement test to determine the actual research knowledge and skills of each student and then place the student in the appropriate section or allow the student to self-select the section but also assess the student's knowledge and skills in addition to perceived ability, to compare actual and perceived abilities in each group. Given the negative stereotypes held by students and practitioners about research (Epstein, 1987; Harder, 2010; Wainstock, 1994), it would be interesting to explore the impact of perception on performance and vice versa.

While there were significant differences at pre-test, this was not the case at post-test. Similar to other research using the RSE (Unrau \& Grinell, 2005), both TM1 and TM2 students felt about equally confident in their research abilities at the end of the course. While one would hope to have high levels of confidence in research ability upon completion, it is particularly interesting that the scores were close in spite of very different tasks completed over the two terms, different content covered, and the fact that TM2 worked on a hypothetical research project versus an actual project. Further research is needed to examine whether it was the effectiveness of the teaching models, simply completing two research courses, or a combination that resulted in comparable post-test scores for both groups.

Although the variance in the TM2 group was not significantly larger, it indicates that students in that group showed greater diversity in their research self-efficacy than students in the TM1 group at the beginning and end of the course. One possible explanation for this is that in addition to students who had none or limited prior research training, there were a number of students in TM2 who (a) had advanced skills but opted to remain in the regular section because they preferred a more structured, didactic environment, (b) may have wanted further instruction before assisting with a research project, or (c) may still lack confidence in their research ability. While there were students in TM1 who had had 
less research experience than others, their strong desire to be in a more applied section may have resulted in high perceived research confidence and ability comparable to those in the section who were more experienced.

The fact that there was a significant increase over time in RSE scores for both groups suggests that both teaching models were effective. This too is supported by the moderate to high levels of endorsement of all items measuring Student Research Confidence. This may be explained by the fact that each model met the specific needs of each learner to enhance their research confidence. For example, those students who wanted an advanced, experiential learning received such an experience which then further enhanced their perceptions of confidence. Those students who might have been less confident and opted for a more structured learning environment flourished in an environment that met their learning style, resulting in higher post-test scores. Another possible explanation may be that while two different models were used, the teaching styles of each instructor were similar in terms of high student engagement and mentorship (i.e., lots of email correspondence, office hours and developing trust and rapport with students) and this level of encouragement, regardless of course format, resulted in higher overall post-test scores. It would be interesting to see how students would have scored in TM2 with a different teaching style but the same format or how TM2 students might have done in a TM1 environment. It may be possible that students with less experience would also do well under a mentorship model and would improve their skills as much as their reportedly more experienced colleagues. The increase over time may also be due to the fact that completing two terms of research courses simply resulted in greater confidence regardless of the model used.

It was interesting to find that TM2 students improved significantly more than TM1 students and had a RSE mean post-test score quite comparable to the TM2 students. One might expect that the improvement would be less dramatic for those who were already advanced since they had less of a learning curve and started off feeling more confident. TM2 students had seemingly greater obstacles to overcome to achieve high post-test scores such as low confidence issues and limited prior knowledge, the need to learn varied and general content pertaining to different research designs rather than what was specifically needed to complete TM1 tasks, and a lack of opportunities for immediate application of their knowledge to practice. As discussed previously, it is difficult to tell whether the significant improvement for TM2 was due to the course format, course content, types of assignments and/or teaching style. Further research is needed which explores the essence of the experience between pre- and post-tests that might result in greater perceptions of confidence and ability.

\section{Conclusion}

This small, exploratory study provides some insight into different models of teaching research to social work Masters level students which can contribute to the limited literature on curriculum design for research courses. While negative stereotypes about research may be prevalent in social work classrooms and practice settings, this study suggests that specific teaching models can instil research confidence in those with limited prior research knowledge and experience, and can enhance confidence for those students who are considered more advanced in their research background. These findings provide support for the need for different models or strategies for teaching research in order to reduce negative stereotypes about research and better prepare students to engage in research as part of their social work practice.

This study is limited by its self-selected sample, the small size of the sample, sample losses, and the fact that the findings are based on only one year (two terms) of the course. While both models appeared to be effective, one should also be cautious about selecting one of these models over the other as a preferred model. Further research is needed which explores different teaching models and the relationship with different teaching and learning styles as well as with students of varying abilities and experiences so that we can find the best methods for improving research skills and confidence for all social work students.

\section{References}

Adam, N., Zosky, D. L., \& Unrau, Y. A. (2004). Improving the research climate in social work curricula: Clarifying learning expectations across BSW and MSW research courses. Journal of Teaching in Social Work, 24(3/4), 1-18. http://dx.doi.org/10.1300/J067v24n03_01

Cameron, P. J., \& Este, D. C. (2008). Engaging students in social work research education. Social Work Education, 27(4), 390-406. http://dx.doi.org/10.1080/02615470701380006

Cox, P., \& Jackson, S. (2003). Editorial. Social Work Education, 22(1), 3-5.

Calderwood, K. A. (2002). Incorporating multiple epistemologies into teaching statistics to social work students. Journal of Teaching in Social Work, 22(1), 17-32. http://dx.doi.org/10.1300/J067v22n01_03

Cournoyer, B. (2004). The Evidence-Based Social Work Skills Book. Boston: Allyn \& Bacon. 
Davis, S. (2003). Statistics anxiety among female African American graduate-level social work students. Journal of Teaching in Social Work, 23(3), 143-158. http://dx.doi.org/10.1300/J067v23n03_12

Eastham, S., Negropontes, J., Walsh, C. A., Ciesielski, M., Harris, J., Jones, S., Rutherford, G., Prinsloo, I \& Aarrestad, S. (2010). Out of the lower depths: The power of the arts for social justice transformation. Reflections: Narratives of Professional Helping, Special Issue on Social Justice, 16(3), 52-61.

Epstein, I. (1987). Pedagogy of the perturbed: Teaching research to the reluctants. Journal of Teaching in Social Work, 1(1), 71-89. http://dx.doi.org/10.1300/J067v01n01_06

Fraser, M. W., \& Lewis, R. E. (1993). Research education in MSW programs: Four competing perspectives. Journal of Social Service Research, 17(3), 71-90. http://dx.doi.org/10.1300/J079v17n03_04

Fraser, M. W., Lewis, R. E., \& Norman, J. L. (1990). Research education in MSW programs: An exploratory analysis. Journal of Teaching in Social Work, 4(2), 83-103. http://dx.doi.org/10.1300/J283v04n04_12

Gallagher, M. B., Cook, C. A. L., Tebb, S., \& Berg-Weger, M. (2003). Practicing social justice: Community-based research, education and practice. Social Thought, 22 (2/3), 27-39. http://dx.doi.org/10.1300/J131v22n02_03

Gambrill, E. (2004). Contributions of Critical Thinking and Evidence-Based Practice to the

Fulfillment of the Ethical Obligations of Professionals. In H.E. Briggs and T.L. Rzepnicki (Eds.) Using evidence in social work practice (Ch. 1). Chicago, IL: Lyceum Books.

Gantt, A., Pinsky, S., Rock, B., \& Rosenberg, E. (1990). Practice and research: An integrative approach. Journal of Teaching in Social Work, 4(1), 129-143. http://dx.doi.org/10.1300/J067v04n01_10

Gibbs, A. (2001). The changing nature and context of social work research. British Journal of Social Work, 31(5), 687-704. http://dx.doi.org/10.1093/bjsw/31.5.687

Gilgun, J. F. (2005). The four cornerstones of evidence-based practice in social work. Research on Social Work Practice, 15(1), 52-61. http://dx.doi.org/10.1177/1049731504269581

Globerman, J., \& Chan, C. (2000). Feminist epistemology and qualitative research: Toward a cross-cultural teaching model. Journal of Teaching in Social Work, 20(3), 81-99. http://dx.doi.org/10.1300/J067v20n03_07

Green, R. G., Bretzin, A., Leininger, C., \& Stauffer, R. (2001). Research learning attributes of graduate students in social work, psychology, and business. Journal of Social Work Education, 37(2), 333-341.

Harder, J. (2010). Overcoming MSW students' reluctance to engage in research. Journal of Teaching in Social Work, 30(2), 195-209. http://dx.doi.org/10.1080/08841231003705404

Hardcastle, D. A., \& Bisman, C. D. (2003). Innovations in teaching social work research. Social Work Education, 22(1), 31-43. http://dx.doi.org/10.1080/02615470309131

Hewson, J., Walsh, C. A., \& Bradshaw, C. (2010). Enhancing social work research education through research field placements. Contemporary Issues in Education Research, 3(9), 7-15.

Holden, G., Barker, K., Meenaghan, T., Rosenberg, G. (1999). Research Self Efficacy: A new possibility for educational outcomes assessment. Journal of Social Work Education, 35(3), 463-476. http://dx.doi.org/10.1080\%2F02615470309131

Howard, M. O., McMillen, C. J., \& Pollio, D. E. (2003). Teaching evidence-based practice: Toward a new paradigm for social work education. Research on Social Work Practice, 13(2), 234-259. http://dx.doi.org/10.1177/1049731502250404

Knee, R. (2002). Can service learning enhance student understanding of social work research? Journal of Teaching in Social Work, 22(1), 213-225. http://dx.doi.org/10.1300/J067v22n01_14

Lazar, A. (1991). Faculty, practitioner, and student attitudes toward research. Journal of Social Work Education, 27(1), $35-40$.

Lewis, C. (2003). Preparing the next generation of researchers. Social Work Education, 22(6), 577-587. http://dx.doi.org/10.1080/0261547032000142689

Machtmes, K., Deggs, D., Johnson, E., Fox, J., Burke, M., Harper, J., Matzke, B., Arcemont, L., Hebert, L., Tarifa, T., Reynaud, A., Regina T. P. A., \& Brooks, C. (2009). Teaching qualitative research methods through service-learning. The Qualitative Report, 14(1), 155-164. Retrieved, March 20, 2012, from http://www.nova.edu/ssss/QR/QR14-1/machtmes.pdf

McLeod, H., \& Walsh, C. A. (2010). Women who become homeless after age 50: Design considerations for homeless shelters. Manuscript submitted for publication (copy on file with author).

McCrystal, P. (2000). Developing the social work researcher through a practitioner research training programme. Social Work Education, 19(4), 359-373. http://dx.doi.org/10.1080/02615470050078366

McNeece, C.A., \& Thyer, B.A. (2004). Evidence-based practice and social work. Journal of Evidence Based Social Work, 1, 7-25. http://dx.doi.org/10.1300/J394v01n01_02 
Montcalm, D. M. (1999). Applying Bandura's theory of self-efficacy to the teaching of research. Journal of Teaching in Social Work, 19(1), 93-107. http://dx.doi.org/10.1300/J067v19n01_08

Rondeau, G. (2001). Challenges that confront social education in Canada. Retrieved from http://www.caddssw-acddess.org/CHALLENGESTHATCONFRONTSOCIALWORK.doc.

Rzepnicki, T.L., \& Briggs, H.E. (2004). Using Evidence in Your Practice. In H.E. Briggs and T.L. Rzepnicki (Eds.), Using evidence in social work practice (Introduction). Chicago, IL: Lyceum Books.

Secret, M., Ford, J., \& Rompf, E. L. (2003). Undergraduate research courses: A closer look reveals complex social work student attitudes. Journal of Social Work Education, 39(3), 411-422.

Smith, D. (2004). Social work and evidence-based practice. London: Jessica Kingsley Publications.

Thyer, B. (2004). Science in Evidence-Based Social Work Practice. In H.E. Briggs and T.L. Rzepnicki (Eds.) Using evidence in social work practice (Ch. 1). Chicago, IL: Lyceum Books

Unrau, Y. A., \& Grinnell Jr., R. M. (2005). The impact of social work research courses on research self-efficacy for social work students. Social Work Education, 24(6), 639-651. http://dx.doi.org/10.1080/02615470500185069

Wainstock, S. L. (1994). Swimming against the current: Teaching research methodology to reluctant social work students. Journal of Teaching in Social Work, 9(1), 3-16. http://dx.doi.org/10.1300/J067v09n01_02

Walsh, C. A., Shier, M. L., Sitter K. C., \& Sieppert, J. D. (2010). Applied methods of teaching about oppression and diversity to graduate social work students: A case example of digital stories. The Canadian Journal for the Scholarship of Teaching and Learning, 1(2)

Walsh, C. A., Rutherford, G. E., \& Sears, A. E. (2010). Fostering inclusivity through teaching and learning action research. Action Research, 8(2), 191-209. http://dx.doi.org/10.1177/1476750309351360

Table 1. Student Research Confidence Means and Standard Deviations on Items, by Group

\begin{tabular}{|l|c|c|}
\hline Item, response range and response options & $\begin{array}{c}\text { TM1 } \\
\text { Mean (sd) } \\
\mathrm{N}=10\end{array}$ & $\begin{array}{c}\text { TM2 } \\
\text { Nean (sd) }\end{array}$ \\
\hline $\begin{array}{l}\text { 1. Relative to other courses you have taken, how you would describe your progress in } \\
\text { this course with regard to applying the course material to the real world (1-3. Much } \\
\text { higher, average, much lower) }\end{array}$ & $1.2(.4)$ & $1.5(.7)$ \\
\hline 2. Confidence in research ability (1-4. Not at all, a little bit, somewhat, very) & $3.5(.7)$ & $3.3(.9)$ \\
\hline 3. Likelihood of doing research in career (1-4. Not at all, a little bit, somewhat, very) & $3.2(.6)$ & $3.2(.9)$ \\
\hline $\begin{array}{l}\text { 4. Research utilization is vital to effective social work practice (1-5. Strongly } \\
\text { disagree, disagree, undecided, agree, strongly agree) }\end{array}$ & $4.6(.5)$ & $4.7(.5)$ \\
\hline $\begin{array}{l}\text { 5. I am a long way from being able to contribute to research (1-5. Strongly disagree, } \\
\text { disagree, undecided, agree, strongly agree) }\end{array}$ & $2.0(1.2)$ & $2.2(1.2)$ \\
\hline $\begin{array}{l}\text { 6. I have developed analytical skills as a consumer of research that enable me to use } \\
\text { existing social work research to determine the best interventions for my professional } \\
\text { practice (1-5. Strongly disagree, disagree, undecided, agree, strongly agree) }\end{array}$ & $4.4(.7)$ & $4.2(.6)$ \\
\hline $\begin{array}{l}\text { 7. I have developed the skills to plan and execute a research project that contributes to } \\
\text { social work knowledge and practice (1-5. Strongly disagree, disagree, undecided, } \\
\text { agree, strongly agree) }\end{array}$ & $4.2(.6)$ & $4.1(.9)$ \\
\hline $\begin{array}{l}\text { 8. I have developed confidence in applying research to the real world (1-5. Strongly } \\
\text { disagree, disagree, undecided, agree, strongly agree) }\end{array}$ & $4.4(.5)$ & $4.2(.6)$ \\
\hline $\begin{array}{l}\text { 9. Likelihood of doing research in my career (1-4. Not at all, a little bit, somewhat, } \\
\text { very) }\end{array}$ & $3.3(.7)$ & $3.4(.9)$ \\
\hline $\begin{array}{l}\text { 10 Confidence in being able to contribute to research (1-4. Not at all, a little bit, } \\
\text { somewhat, very) }\end{array}$ & $3.5(.5)$ & $3.2(.8)$ \\
\hline $\begin{array}{l}\text { 11. Confidence in planning and executing a research project that contributes to social } \\
\text { work knowledge and practice. (1-4. Not at all, a little bit, somewhat, very) }\end{array}$ & $3.4(.5)$ & $3.2(.9)$ \\
\hline $\begin{array}{l}\text { 12. Confidence in analytical skills as a consumer of research that enable me to use } \\
\text { existing social work research to determine best interventions for my social work } \\
\text { practice. (1-4. Not at all, a little bit, somewhat, very) }\end{array}$ & $3.5(.5)$ & $3.6(.5)$ \\
\hline
\end{tabular}




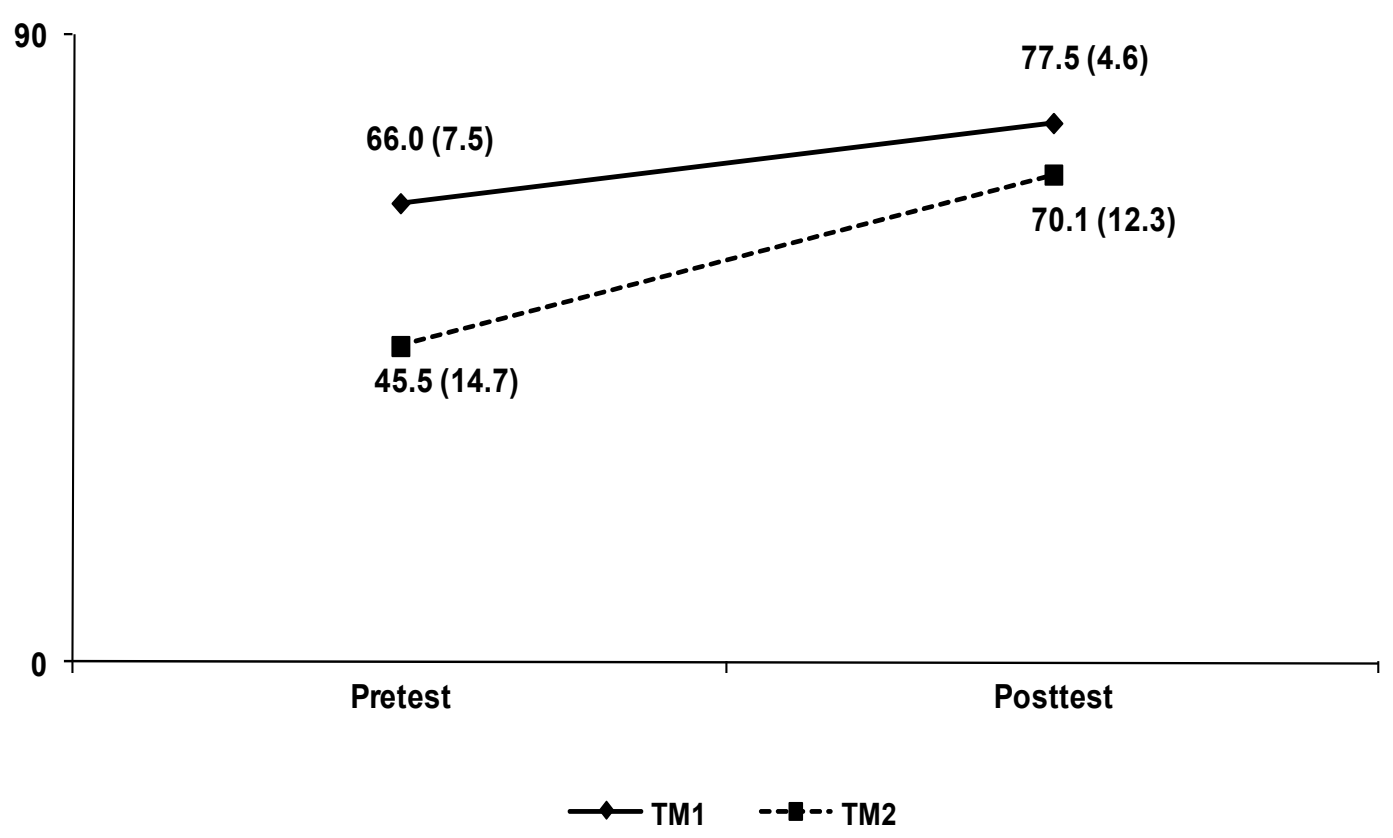

Figure 1. RSE Mean Scores and Standard Deviations, Pre- and Post-test, by Group 